\title{
Functional Characterization of the Pacific Oyster, Crassostrea gigas (Bivalvia: Ostreidae), Hemocytes Under Normoxia and Short-Term Hypoxia
}

\author{
Aleksandra Yu. Andreyeva ${ }^{1}$, Ekaterina S. Kladchenko $\left.{ }^{1, *}{ }^{(}\right)$, Oksana Y. Vyalova ${ }^{1}$, \\ Tatiana A. Kukhareva ${ }^{1}$
}

${ }^{1}$ Department of Animal Physiology and Biochemistry, Moscow representative office A.O. Kovalevsky Institute of Biology of the Southern Seas of RAS Leninsky ave 38, 119991, Moscow, Russian Federation

\section{Article History}

Received 26 August 2020

Accepted 26 December 2020

First Online 28 December 2020

\section{Corresponding Author \\ Tel.: +79787789642 \\ E-mail: kladchenko_ekaterina@bk.ru}

\section{Keywords}

Crassostrea gigas

Hypoxia

Hemocytes

\section{Introduction}

Hypoxic areas or even persistent oxygen minimum zones (OMZ) (Levin, 2002) has become ubiquitous in coastal and open ocean environments since 1950-ies (Gewin, 2010; Middelburg \& Levin, 2009). Coastal hypoxia has expanded in recent decades (Rabalais \& Turner, 2001) negatively influencing biodiversity of resident organisms and fisheries. Climate models predict general decrease of oxygen concentration in World Ocean and spreading of $\mathrm{OMZ}$ in conditions of global warming (Beszczynska-Möller et al., 2012; Deutsch et al., 2011; Melzner et al., 2013; Chan F. et al. 2019; Zhao et al., 2020). Shelf macroorganisms are usually characterized with low tolerance to hypoxia and up to $50 \%$ of coastal species die at oxygen concentration less than $70 \mathrm{mM} \mathrm{kg}^{-1}$ (Vaquer-Sunyer \& Duarte, 2008; Young \& Gobler, 2020).

Due to a prominent ecological role and economic importance of bivalves, the influence of hypoxia on mollusks' physiology has been intensively studied in recent years (van der Schatte Olivier et al., 2020; Gu et al., 2019). Low oxygen induces various physiological disturbances in bivalves, which occurs as a result of decreased protein synthesis and general suppression of aerobic metabolism (Gewin, 2010; Hochachka \& Somero, 2002). Hypoxia causes disruptions of growth rate, immunity status and other parameters which are important for cultivated species (Clark et al., 2013).

The Pacific oyster (Crassostrea gigas), a commercially important bivalve mollusk, usually inhabit shallow intertidal areas, which frequently became hypoxic due to eutrophication and poor water mixing (Gray et al., 2002; Melzner et al., 2013; Wu, 2002). It is generally considered that species from Ostreidae family possess 3 types of hemocytes: agranulocytes, hyalinocytes and granulocytes (Ford et al., 1994; Picot et al., 2019; Hong et al., 2012). Oyster granulocytes are the main hemocyte type involved in cellular immune responses as they are more active in phagocytosis compared with agranulocytes and hyalinocytes (Wang et al., 2017). The hyalinocytes possess lower ability to 
phagocytosis, and agranulocytes, in turn, are not able to phagocytoze (Terahara et al., 2006; Takahashi et al., 2017; Jiang et al., 2018). Other bivalve species demonstrate similar specialization of hemocytes (Cheng \& Rifkin, 1970; Foley \& Cheng, 1975; Wang et al., 2017; Wu et al., 2018; Sui et al., 2016). Despite that, precise functional role of agranular cells is not clear yet, although they also perform cellular immune responses and may be involved in the processes of wound healing (Suzuki \& Funakoshi, 1992).

Non-specific immunity parameters are considered to be critically important for assessment of physiological state of cultivated bivalves. Innate immune system of bivalve mollusks is ensured by hemocytes circulating in hemolymph and non-specific tissue humoral factors (Song et al., 2010). Cellular immune responses typically involve phagocytosis and encapsulation of invading agents, and production of cytotoxic products and intracellular reactive oxygen species (ROS) (CochennecLaureau et al., 2003; Li et al., 2014; Song et al., 2010; Wang et al., 2018). Low dissolved oxygen greatly influences non-specific immune responses in bivalve mollusks (Wang et al., 2018). Decreased total hemocyte number, intensity of phagocytosis, lower lysosomal content, increased hemocyte mortality and the content of reactive oxygen species were observed in Perna viridis and Mytilus coruscus under hypoxia (Sui et al., 2016, Wang et al., 2012, 2014; Sussarellu et al., 2012). At the cellular level, hypoxia causes inhibition of aerobic respiration in mitochondria (Sussarellu et al., 2013) and the increase of expression of antioxidant enzymes (Sussarellu et al., 2010). Oxygen is also essential for ROS production, which are involved in the process of pathogen degradation during phagocytosis (Donaghy et al., 2013; Hermes-Lima et al., 2015). 48-h incubation of oysters (Crassostrea virginica) in low-oxygen water led to $70 \%$ decrease of ROS production by hemocytes (Boyd \& Burnett, 1999). On the other hand, short-term hypoxia did not cause such effects in $C$. gigas (Sussarellu et al., 2012).

Considering that global decrease of dissolved oxygen is an emerging concern for coastal aquaculture the aim of the present work was to examine effects of $24 \mathrm{~h}$ hypoxia on hemolymph cellular composition and functional parameters of hemocytes of the Pacific oyster (C. gigas) cultivated in the Black sea.

\section{Materials and Methods}

\section{Maintaining of Mollusks}

Adult oysters ( $C$. gigas) of both sexes (shell length $94 \pm 3.5 \mathrm{~mm}, 23 \pm 4.2 \mathrm{~g}, \mathrm{n}=16$ ) were obtained from shellfish farm (Salt Lake Donuzlav, Crimea) during October 2017-November 2017. Oysters were divided on 2 groups (8 individuals in each group) and kept in $30 \mathrm{~L}$ tanks equipped with flowing sea water system (oxygen

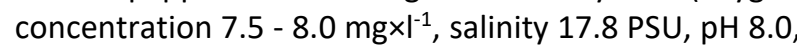

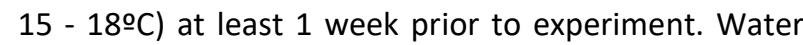

temperature, salinity and acidity corresponded to that observed in natural habitat conditions of oysters in the Black Sea. During the acclimation period oysters were fed daily with mixture of microalgae.

\section{Hypoxia Modeling}

Oxygen concentration in the tank with oysters was decreased to $0.2 \mathrm{mg} \mathrm{L}^{-1}$ by bubbling of seawater with nitrogen gas. Hypoxic conditions were maintained for 24 $\mathrm{h}$ and the concentration of oxygen was monitored regularly (oxygen sensor Ohaus Starter 300 D, USA) and kept at constant level throughout the experiment.

\section{Hemolymph Sampling}

After $24 \mathrm{~h}$ incubation period $0.5-1.0 \mathrm{ml}$ hemolymph was collected from each oyster with a 25 gauge needle and 2-ml plastic syringe. Hemolymph from individual oysters was analyzed separately. After sampling, hemolymph was filtered to $20 \mu \mathrm{m}$ mesh to eliminate aggregates or large pieces of debris and cells were separated by centrifugation $(500 \mathrm{~g}, 5 \mathrm{~min}$ ). The pellet was washed twice and resuspended in sterile filtered $(0.2 \mu \mathrm{m})$ sea water. To prevent hemocyte clumping, all manipulations with samples were held on ice. After the final washing slides were prepared.

\section{Light Microscopy of Hemocytes}

Slides were dried on air at least $24 \mathrm{~h}$ and then fixed and dyed with May Grünwald and Giemsa stain solutions. Hemocytes were viewed on light microscope (Biomed PR-2 Lum) equipped with camera (Levenhuk C NG Series). Approximately 1000 cells per smear were examined. Morphometric analysis was performed using ImageJ 1.44 p. For each hemocyte the largest cellular and nuclear diameter has been measured. The nucleocytoplasmic ratio was calculated using the equation:

$$
\mathrm{N} / \mathrm{C} \text { ratio }=\text { nucleus diameter } / \text { cell diameter }
$$

\section{Flow Cytometry}

For flow cytometry analysis, hemocyte concentration in the suspension adjusted to 1$2 \times 10^{6}$ cell ml $^{-1}$. Cells were analyzed on FC500 flow cytometer (Beckman Counter) equipped with an aircooled argon laser, providing a laser excitation at 488 $\mathrm{nm}$. An FSC threshold was defined in order to eliminate cell debris and bacteria and 50000 events were counted for each sample. Suspensions were dyed with DNAbinding fluorochrome SYBR Green I (final concentration in the probe $10 \mu \mathrm{M})$, and hemocytes were readily differentiated from other particles in the hemolymph on the basis of the dye fluorescence. Results are expressed as cell cytograms indicating the size (FSC value), the granularity (SSC value) and the level of fluorescence using the corresponding channel of fluorescence. 


\section{Intracellular ROS Production}

The production of reactive oxygen species (ROS) by hemocytes was assessed using 2-7-dichlorofluoresceindiacetate (DCF-DA). Working solution of DCF-DA was prepared by the dilution of the dye in DMSO and kept frozen $(-20 \circ \mathrm{C})$. Hemocyte suspensions $(1 \mathrm{ml})$ were incubated with $10 \mu \mathrm{l}$ of DCF-DA solution for $30 \mathrm{~min}$ in the dark. During staining, the dye was oxidized to highly fluorescent dichlorofluorescein (DCF) in hemocyte cytoplasm. The level of fluorescence represents the capacity of cells to generate ROS. The green fluorescence produced by DCF was registered by the FL1 detector.

\section{Hemocyte Proliferation}

DNA content and hemocyte proliferation were determined on a single-parameter histograms of SYBR Green I fluorescence in FL1-channel. The number of proliferating cells was estimated using standard cell cycle analysis, by the number of cells in S-, G2- and Mstages (Nunez, 2001). Cell aggregates were discriminated on amplitude versus width plots of SYBR Green I fluorescence.

\section{Mortality Level}

The number of dead cells in hemolymph was investigated by the analysis of the fluorescence of hemocytes stained with Propidium iodide (PI). $10 \mu \mathrm{l}$ of $200 \mu \mathrm{g} \mathrm{ml}^{-1} \mathrm{PI}$ stock solution (Sigma Aldrich) was added to $1 \mathrm{ml}$ hemocyte suspension, and the cells were incubated in the dark for $30 \mathrm{~min}$ at 4 ㅇ C. The percentage of dead hemocytes was evaluated on the histograms of PI fluorescence in the channel FL4 of cytometer.

\section{Percoll Centrifugation}

To characterize each hemocyte subpopulation, cells were separated by centrifugation in a discontinuous Percoll gradient according to the protocol used for molluskan hemocytes (López et al., 1997). 0.5 $\mathrm{ml}$ of hemocytes suspensions was layered over a $1.5 \mathrm{ml}$ of discontinuous gradient and centrifuged at $400 \mathrm{~g}$ for $10 \mathrm{~min}$ in centrifuge Elmi CM-80 (Russia). Cells from each layer were collected separately and gently washed twice in sterile filtered sea water to remove Percoll. The pellet was divided for flow cytometric and light microscopic analysis (see 2.4). Each layer was analyzed separately.

\section{Data Analysis}

All flow cytometric measurements were performed at least at 3 replicates. One-way analysis of variance (ANOVA) and Tukey's test were carried out to compare the means. Differences were considered significant at $P \leq 0.05$. The results are expressed as the means and standard errors.

\section{Results}

No mortality of oysters was observed during acclimation period and $24 \mathrm{~h}$ hypoxia exposure. Total survival of the animals was $100 \%$.

\section{Light Microscopy}

Microscopic observation allowed distinguishing three cell types in hemolymph of oysters: agranulocytes, hyalinocytes, and granulocytes (Figure 1). Agranulocytes were round cells with large rough basophilic nucleus and narrow cytoplasm. Agranulocytes did not form pseudopodia. Relatively large granulocytes possessed ameboid shape, cytoplasm had granules (basophilic, eosinophilic or mixed color); small eccentric nuclei contained heterochromatin. Hyalinocytes were characterized with intermediate cellular diameter and their morphology was similar to that in granulocytes, however, basophilic nuclei were situated in the center of cell and basophilic cytoplasm did not contain granules. Morphometric parameters of hemocytes are presented in Table 1.

Despite the average diameter of agranulocytes, hyalinocytes and granulocytes significantly differed $(P<$ $0.05, \mathrm{n}=16)$, we also observed agranular cells with cellular diameter close to that for granulocytes. Similarly, some granulocytes were almost the same size as agranulocytes. The diameter of hyalinocytes varied in the wide range partly overlapping agranulocytes and granulocytes dimensions.

\section{Flow Cytometry}

Hemolymph samples stained with SYBR Green I were plotted by forward scatter (FSC) and side scatter (SSC). SYBR Green I positive cells revealing a single peak of green fluorescence were considered as the hemocyte population. Hemocytes were relatively homogenous by DNA content. No proliferation was observed. The CV of diploid peak was $15.7 \pm 0.7$ (Figure 2). The percentage of hemocytes found to be nonviable were low in all hemolymph samples ( $\leq 10 \%)$.

Three cell populations differing by size and granulation could be detected in $C$. gigas hemolymph (Figure 3). Subpopulation 1 consisted of small nongranulated cells amounting $24.3 \pm 2.7 \%$ of total cell count. Subpopulation 2 comprised large cells with moderate level of granularity (SSC). These cells were the most abundant in hemolymph $(62.4 \pm 2.7 \%$ of total cell count). Cells in the subpopulation 2 greatly varied by their FSC and SSC level. Subpopulation 3 was the smallest in number $(13.2 \pm 1.7 \%)$ and contained the largest cells with the highest granularity level.

\section{ROS Production}

All cells in suspension exhibited bright fluorescence of DCF-DA differing by the intensity among 


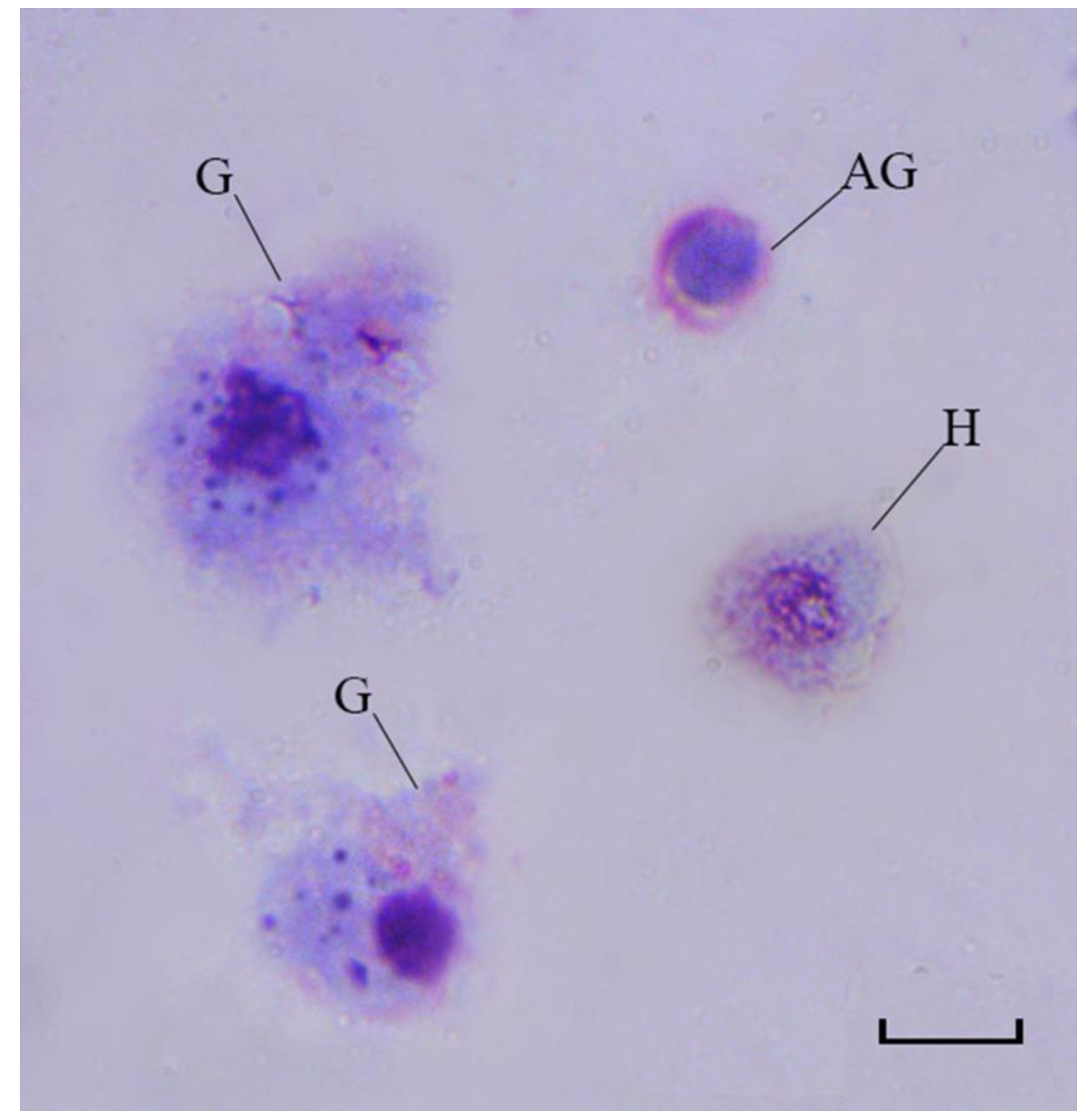

Figure 1. The morphology of $C$. gigas hemocytes: AG- agranulocytes; H-hyalinocytes; G- granulocytes. Slides were stained with May Grünwald and Gimsa solutions and viewed in light microscope. Morphometric analysis was performed in the ImageJ program. Bar: $10 \mu \mathrm{m}$

Table 1. Morphometric analysis of $C$. gigas hemocytes. Mean $\pm \mathrm{SE}$ and rank of variation corresponding to cell diameter. nucleus diameter and N/C ratio of each hemocyte type are shown. AG: agranulocyte; $\mathrm{H}$ : hyalinocyte; G: granulocyte.

\begin{tabular}{llcccccccc}
\hline & \multicolumn{3}{c}{ Nucleus $(\mu \mathrm{m})$} & \multicolumn{3}{c}{ Cell $(\mu \mathrm{m})$} & \multicolumn{3}{c}{ N/C ratio } \\
\hline & Mean \pm SD & Min & Max & Mean \pm SD & Min & Max & Mean $\pm S D$ & Min & Max \\
AG & $5.5 \pm 0.1$ & 2.4 & 12.1 & $9.1 \pm 0.1$ & 4.0 & 20.4 & $0.6 \pm 0.01$ & 0.4 & 0.9 \\
H & $4.0 \pm 0.1^{*}$ & 1.2 & 8.4 & $9.7 \pm 0.2^{*}$ & 4.4 & 18.2 & $0.4 \pm 0.01^{*}$ & 0.2 & 0.6 \\
$\mathrm{G}$ & $3.0 \pm 0.1^{*}$ & 1.3 & 7.6 & $11.1 \pm 0.4^{*}$ & 5.0 & 23.4 & $0.3 \pm 0.01^{*}$ & 0.1 & 0.5 \\
\hline
\end{tabular}

* shows a significant differences $(P<0.05)$ between hyalinocyte and agranulocyte types; agranulocyte and granulocyte types.

subpopulations. Subpopulation 1 possessed significantly lower DCF fluorescence compared to subpopulation 2 and subpopulation 3 . Subpopulation 2 cells had 3 times higher intensity of the dye fluorescence compared to subpopulation 1 . The largest granulated cells were characterized with the highest DCF fluorescence in suspension.

\section{Percoll Density Gradient}

Density gradient centrifugation demonsrated three hemocyte layers in hemolymph. The lowest layer (cells with larger density) contained mainly granulocytes and small number of hyalinocytes. Hyalinocytes observed in this layer were larger comparing to mean size for this cell type. The top layer was formed by the cells with the lowest density agranulocytes. Some hyalinocytes were also observed in this layer. The intermediate layer was mainly formed by large agranulocytes and low-granulated granulocytes.

\section{Hypoxic Impact}

The cellular composition of oysters' hemolymph. subjected to hypoxia underwent substantial changes. Flow cytometric observation demonstrated significant increase of agranulocyte number $(37.4 \%$ for control group versus $95.3 \%$ for hypoxic probes). The number of granulocytes and hyalinocytes decreased to $3.9 \%$ and $0.7 \%$ in hypoxic specimens respectively. No significant changes in the level of dead cells hemocyte morphology and proliferation of cells were observed. Hypoxia substantially decreased the ability of hemocytes to produce ROS. The level of DCF-DA fluorescence in all subpopulations of cells was significantly lower comparing to normoxic probes (Figure 4). 


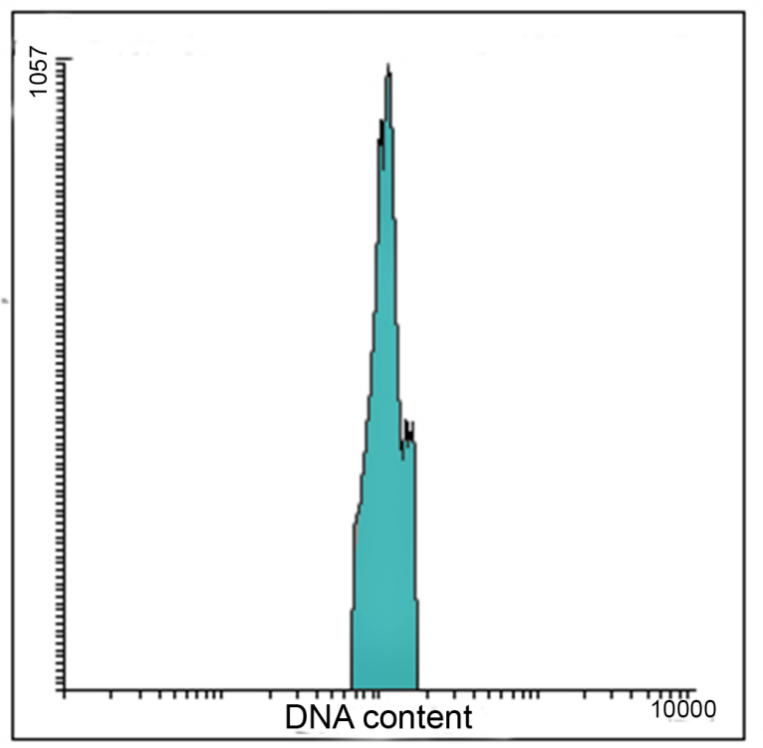

Figure. 2. DNA content in hemocytes of $C$. gigas. Histogram represents SYBR Green I-positive non-proliferating cells in suspensions of hemocytes.

Table 2. Spontaneous ROS production by $C$. gigas. hemocytes. The analysis of ROS production by cells was based on the intensity of DCF-DA fluorescence (Mean $\pm \mathrm{SE}$ ) in non-stimulated hemocytes.

\begin{tabular}{lc}
\hline Cell type & DCF-DA fluorescence (arbitrary units) \\
\hline Subpopulation 1 & $418 \pm 14.11$ \\
Subpopulation 2 & $1290.33 \pm 72.67^{*}$ \\
Subpopulation 3 & $5041.89 \pm 362.62^{*}$ \\
\hline
\end{tabular}

* represents significant differences between average value of fluorescence between subpopulations. $\mathrm{P} \leq 0.05$

\section{Discussion}

\section{Hemocytes Classification}

We identified 3 types of $C$. gigas hemocytes that corresponds to classification previously shown by other researchers (Ford et al., 1994; Picot et al., 2019; Hong et al., 2012) The main morphological features of oysters' granulocytes (low N/C ratio. numerous granules in cytoplasm. small eccentric nucleus and pseudopodia) were similar to those already reported (Chang et al., 2005). Some authors subdivided granulocytes into basophilic, eosinophilic and intermediate cells according to the color of granules (Aladaileh et al., 2007; Chang et al., 2005). In spite of observing granulocytes with granules differently colored we did not used this morphological criterion for distinguishing subpopulations as it could be subjective. Density centrifugation of hemolymph demonstrated only three cellular layers and three subsets of cells could be identified in flow cytometry plots, which agrees with previously published data (Bachère et al., 1988). The controversies around the nomenclature of agranular hemocytes in Ostreidae family substantially complicate comparison of the cells morphology and functions described in published works. In the present study there were two subtypes of agranular cells in hemolymph, agranulocytes (the smaller ones) and hyalinocytes (the larger agranular cells). These cell types differed by their nucleo-cytoplasmic ratio and the ability to form pseudopodia. Hyalinocytes and granulocytes had similar cellular and nuclear diameters to those found in previous works on C.gigas (Ford et al., 1994) and C.virginica (Allam et al., 2002). Oysters had larger agranulocytes $(9.1 \mu \mathrm{m} \quad$ v. $8.0 \mu \mathrm{m})$ and smaller granulocytes $(11.1 \mu \mathrm{m} \quad$ v. $12.7 \mu \mathrm{m})$ than mussels (Andreyeva et al., 2019). In several works small agranulocytes are sometimes classified as blast-like cells (hemocytoblasts), which are suggested to be stem cells freely circulating in the hemolymph (Hine, 1999). Cells with similar morphology are also called 'small hyalinocytes' (Sun et al., 2006). In the present work agranulocytes had a wide range of cell diameter (4 to 20 $\mu \mathrm{m})$ and the smallest cells had close diameter and morphology to blast-like hemocytes. Overlap of the range of cell diameter between cell types in the hemolymph observed in this work, and the presence of low- and high- granulated granulocytes in hemolymph may indicate, that agranular cells (i.e. agranulocytes and hyalinocytes) are stages of granulocyte maturation. This hypothesis is indirectly confirmed by the gradual decrease of NCR from agranulocytes to hyalinocytes and granulocytes, as immature vertebrate blood cells usually have larger nucleus compared to mature ones 
A
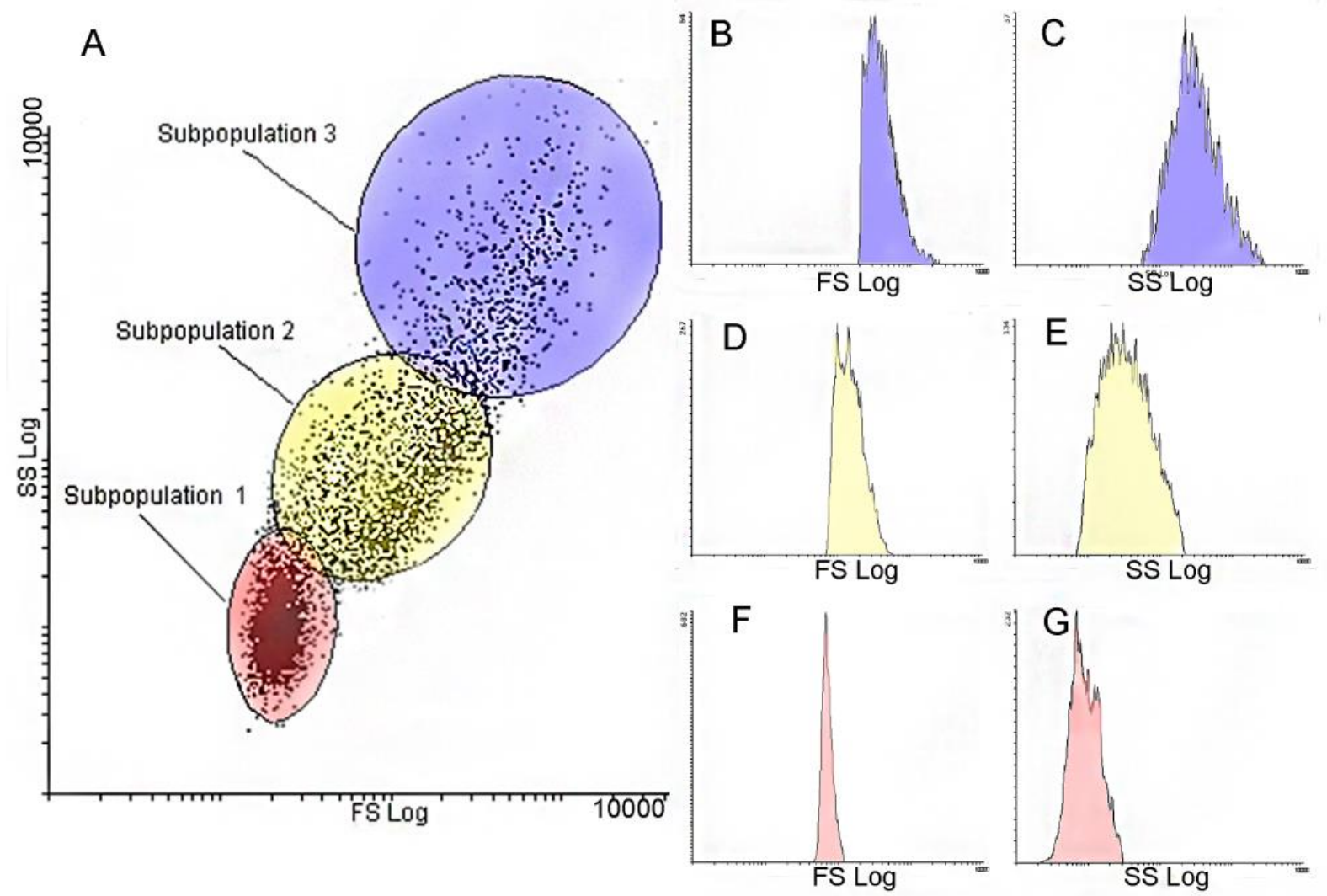

Figure 3. The distribution of $C$. gigas hemocytes by arbitrary size and granulation level. A -Forward scatter (FSC) vs. side scatter (SSC) density plot shows SYBR Green I- positive cells forming three populations (Subpopulation 1.2.3). B. D. F - characterization of cells in subpopulation 3. 2. 1 respectively by the arbitrary diameter; C. E. F - distribution of cells within subpopulation 3. 2. 1 according to granularity criteria. Hemocyte concentration in sterile filtered sea water was $1-2 \cdot 10^{6} \mathrm{cell} \mathrm{ml}^{-1}$; cells were incubated with SYBR Green I with final concentration in the probe $10 \mu \mathrm{M}$.
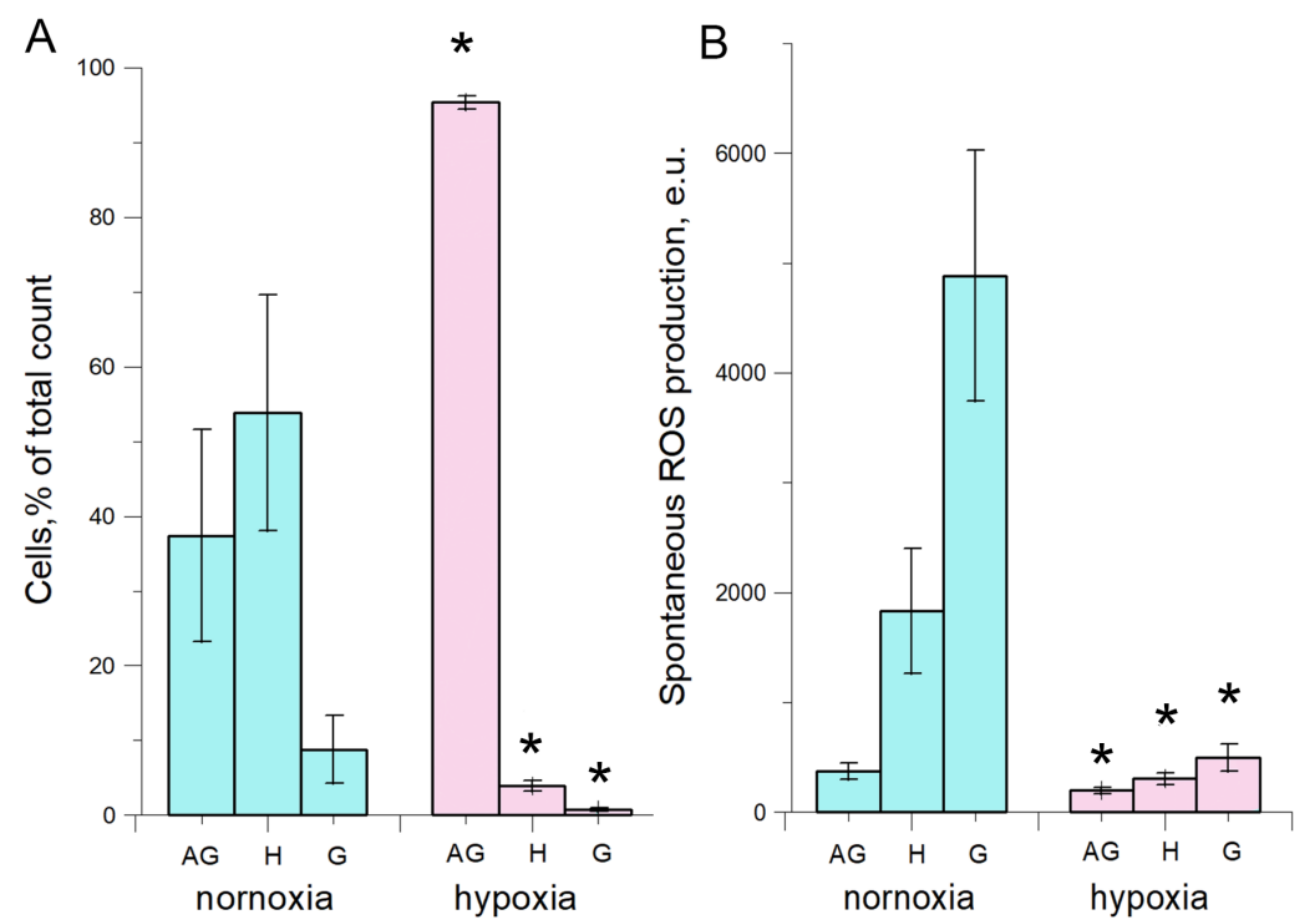

Figure 4. Hypoxia causes changes in cellular composition of $C$. gigas hemolymph and their ability to produce ROS. A - ratio between subpopulations of cells in hemolymph; B - The level of spontaneous ROS production by subpopulations of hemocytes. ROS production by cells was based on the intensity of DCF-DA fluorescence (mean $\pm \mathrm{SE}$ ) in non-stimulated hemocytes. * represents significant differences between average value of fluorescence between cell types. $P \leq 0.05$. 
(Andreyeva et. al., 2017; van der Knaap et al., 1993). However, site of hemocyte proliferation is supposed to occur outside the circulation system as we did not observe hemocyte proliferation in hemolymph.

\section{Hypoxic Impact}

24-h hypoxia substantially influenced functional parameters of hemocytes. Spontaneous ROS production decreased in all cell types. Similar tendency was previously reported for C.gigas (Table 2) (Donaghy et al., 2013) and other bivalve species (Andreyeva at al., 2019; Boyd \& Burnett. 1999; Wang et al., 2012). Oxygen is essential for production of intracellular ROS and the decrease observed may be at least partly caused by the inhibition of respiration in mitochondria (Donaghy et al., 2012). 24-h hypoxia influenced the agranular and granular cells differently. ROS production in granulocytes decreased more than 9 times. Hyalinocytes and agranulocytes of oysters demonstrated respectively 6 and 2 times lower fluorescence of DCF-DA compared to normoxic probes. Such differences in the degree of hypoxic impact on intracellular ROS production between hemocytes may be caused by the functional role and the morphological structure of each cell type. Granulocytes are more oxygen demanding cells compared to agranular cells, because they possess complicated ultrastructure with numerous mitochondria and endoplasmic reticulum (Chang et al., 2005). These morphological properties presume granulocytes as greater oxygen consumers comparing to agranulocytes which in turn leads to their greater sensitivity to low dissolved oxygen level.

Hemolymph of oysters held in hypoxic conditions contained increased number of agranulocytes. The number of hyalinocytes and granulocytes decreased. Similar changes in agranulocyte number have been previously reported for $C$. gigas after 24-h hypoxia at oxygen concentrations $2.6 \mathrm{mg} \mathrm{O}_{2} \mathrm{~L}^{-1}$ (Sussarellu et al., 2012). The processes involved in modulation of hemolymph cellular composition in bivalves under hypoxia are not clear. In lower vertebrates rapid increase of red blood cell number in circulating blood after exposure to hypoxia is usually caused by release of cells from spleen (Fange \& Nilsson, 1985; Houston et al., 1996; Strunjak-Perovic et al.. 2009; Abdel-Tawwab et al., 2019; Soldatov A. A. et al., 2017). Changes in blood cell composition following chronic or long-term hypoxia are associated with the enhancement of erythropoiesis in hematopoietic tissues (Moritz et al., 1997; Soldatov, 2005; Van der Weele \& Jeffery, 2019). Increased hematopoiesis seems unlikely due to short-term exposure to hypoxia. In the present work we did not observe hemocyte proliferation in normoxic or hypoxiatreated mollusks. Hemocyte migration from other tissues is an alternative process that may be associated with changes in the hemolymph cell composition during hypoxia (Donaghy et al., 2012; Ottaviani et al., 1998).
In summary, hemolymph of the Pacific oyster contains 3 hemocyte types, two of which are agranular cells (agranulocytes and hyalinocytes) and one is granulocytes. Agranular cells are supposed to be immature granulocytes. However, hematopoiesis of hemocytes does not occur in hemolymph. The results of the study indicate that 24-h hypoxic exposure causes considerable changes in physiology of oysters. At the organismic level the fluctuations in hemolymph cellular composition are observed, i.e. the number of agranulocytes increased. At the cellular level incubation in low dissolved oxygen led to decrease of spontaneous ROS production by hemocytes, but did not induce hemocyte mortality.

\section{Acknowledgements}

The work on the describing the morphology of hemocytes is partly supported by State Assignment (state registration number $\mathrm{N}$ 0828-2019-0003) and hypoxic impact on oysters has been investigation with the support of Grants Council of the President of the Russian Federation (project MK-609.2020.4)

\section{References}

Abdel-Tawwab, M., Monier, M.N., Hoseinifar, S.H., \& Faggio, C. (2019). Fish response to hypoxia stress: growth, physiological, and immunological biomarkers. Fish Physiology and Biochemistry, 45(3), 997-1013. https://doi.org/10.1007/s10695-019-00614-9

Aladaileh, S., Nair, S.V., Birch, D. \& Raftos, D.A. (2007). Sydney rock oyster (Saccostrea glomerata) hemocytes: morphology and function. Journal of invertebrate pathology, 96(1), 48-63. https://doi.org/10.1016/j.jip.2007.02.011

Allam, B., Ashton-Alcox, K.A., \& Ford, S.E. (2002). Flow cytometric comparison of haemocytes from three species of bivalve molluscs. Fish \& shellfish immunology, 13(2), 141-158. https://doi.org/10.1006/fsim.2001.0389

Andreyeva, A.Y., Efremova, E.S. \& Kukhareva, T.A. (2019). Morphological and functional characterization of hemocytes in cultivated mussel (Mytilus galloprovincialis) and effect of hypoxia on hemocyte parameters. Fish \& shellfish immunology, 89, 361-367. https://doi.org/10.1016/j.fsi.2019.04.017

Andreyeva, A.Y., Soldatov, A.A. \& Kukhareva, T.A. (2017). Black scorpionfish (Scorpaena porcus) hemopoiesis: Analysis by flow cytometry and light microscopy. The Anatomical Record, 300(11), 1993-1999.

https://doi.org/10.1002/ar.23631

Bachère, E., Chagot, D. \& Grizel, H. (1988). Separation of Crassostrea gigas hemocytes by density gradient centrifugation and counterflow centrifugal elutriation. Developmental \& Comparative Immunology. 12(3), 549559. https://doi.org/10.1016/0145-305X(88)90071-7

Beszczynska-Möller, A., Fahrbach, E., Schauer, U. \& Hansen, E. (2012). Variability in Atlantic water temperature and transport at the entrance to the Arctic Ocean. 19972010. ICES Journal of Marine Science, 69(5), 852-863. https://doi.org/10.1093/icesjms/fss056 
Boyd, J.N. \& Burnett, L.E. (1999). Reactive oxygen intermediate production by oyster hemocytes exposed to hypoxia. Journal of Experimental Biology, 202(22), 31353143.

Chan, F., Barth, J.A., Kroeker, K.J., Lubchenco, J., \& Menge, B.A. (2019). The dynamics and impact of ocean acidification and hypoxia. Oceanography, 32(3). 62-71. https://doi.org/10.5670/oceanog.2019.312

Chang, S.J., Tseng, S.M. \& Chou, H.Y. (2005). Morphological characterization via light and electron microscopy of the hemocytes of two cultured bivalves: a comparison study between the hard clam (Meretrix lusoria) and Pacific oyster (Crassostrea gigas). Zoological studies, 44(1), 144-153. https://doi.org/10.1016/j.micron.2016.03.003

Cheng, T.T. \& Rifkin, E. (1970). Cellular reactions in marine molluscs in response to helminth parasitism. Special Publications. American Fisheries Society, (5), 443-496.

Clark, M.S., Husmann, G., Thorne, M.A., Burns, G., Truebano, M., Peck, L.S. \& Philipp, E.E. (2013). Hypoxia impacts large adults first: consequences in a warming world. Global Change Biology, 19(7), 2251-2263. https://doi.org/10.1111/gcb.12197

Cochennec-Laureau, N., Auffret, M., Renault, T. \& Langlade, A. (2003). Changes in circulating and tissue-infiltrating hemocyte parameters of European flat oysters Ostrea edulis, naturally infected with Bonamia ostreae. Journal of invertebrate pathology, 83(1), 23-30. https://doi.org/10.1016/S0022-2011(03)00015-6

Deutsch, C., Brix, H., Ito, T., Frenzel, H. \& Thompson, L. (2011). Climate-forced variability of ocean hypoxia. Science, 333(6040), 336-339. https://doi.org/10.1126/science.1202422

Donaghy, L., Artigaud, S., Sussarellu, R., Lambert, C., Le Goïc, N., Hégaret, H. \& Soudant. P. (2013). Tolerance of bivalve mollusc hemocytes to variable oxygen availability: a mitochondrial origin? Aquatic Living Resources, 26(3), 257-261. https://doi.org/10.1051/alr/2013054

Donaghy, L., Kraffe, E., Le Goïc, N., Lambert, C., Volety, A.K. \& Soudant, P. (2012). Reactive oxygen species in unstimulated hemocytes of the Pacific oyster Crassostrea gigas: a mitochondrial involvement. PloS one, $7(10)$, e46594.

https://doi.org/10.1371/journal.pone.0046594

Fänge, R. \& Nilsson, S. (1985). The fish spleen: structure and function. Experientia, 41(2), 152-158.

Foley, D.A. \& Cheng, T.C. (1975). A quantitative study of phagocytosis by hemolymph cells of the pelecypods Crassostrea virginica and Mercenaria mercenaria. Journal of invertebrate pathology, 25(2), 189-197.

Ford, S.E., Ashton-Alcox, K.A. \& Kanaley, S.A. (1994). Comparative cytometric and microscopic analyses of oyster hemocytes. Journal of Invertebrate Pathology, 64(2), 114-122. http://doi.org/10.1006/jipa.1994.1079

Gewin, V. (2010). Dead in the water. Nature, 466(7308), 812. http://doi.org/10.1038/466812a

Gray, J.S., Wu, R.S.S. \& Or, Y.Y. (2002). Effects of hypoxia and organic enrichment on the coastal marine environment. Marine ecology progress series, 238, 249-279. http://doi.org/10.3354/meps238249

Gu, H., Shang, Y., Clements, J., Dupont, S., Wang, T., Wei, S., ... \& Wang, Y. (2019). Hypoxia aggravates the effects of ocean acidification on the physiological energetics of the blue mussel Mytilus edulis. Marine pollution bulletin, 149, 110538

http://dx.doi.org/10.1016/j.marpolbul.2019.110538
Hermes-Lima, M., Moreira, D.C., Rivera-Ingraham, G.A., Giraud-Billoud, M., Genaro-Mattos, T.C. \& Campos, É.G. (2015). Preparation for oxidative stress under hypoxia and metabolic depression: revisiting the proposal two decades later. Free Radical Biology and Medicine, 89, 1122-1143. https://doi.org/10.1016/j.freeradbiomed.2015.07.156

Hine, P.M. (1999). The inter-relationships of bivalve haemocytes. Fish \& Shellfish Immunology, 9(5), 367-385. http://doi.org/10.1006/fsim.1998.0205

Hochachka, P.W. \& Somero, G.N. (2002). Biochemical adaptation: mechanism and process in physiological evolution. Oxford University Press. https://doi.org/10.1515/9781400855414

Hong, H.K., Kang, H.S., Kim, Y.O., \& Choi, K.S. (2012). Assessment of immune parameters of the wild pacific oyster (Crassostrea gigas) using a flow cytometry and neutral red retention assay. Ocean and Polar Research, 34(2), 137-149. https://doi.org/10.4217/OPR.2012.34.2.137

Houston, A.H., Roberts, W.C. \& Kennington, J.A. (1996). Hematological response in fish: pronephric and splenic involvements in the goldfish Carassius auratus L. Fish Physiology and Biochemistry, 15(6), 481-489. http://doi.org/10.1007/BF01874922

Jiang, S., Qiu, L., Wang, L., Jia, Z., Lv, Z., Wang, M., ... \& Song, L. (2018). Transcriptomic and quantitative proteomic analyses provide insights into the phagocytic killing of hemocytes in the oyster Crassostrea gigas. Frontiers in immunology, 9, 1280. https://doi.org/10.3389/fimmu.2018.01280

Levin, L.A. (2002). Oxygen minimum zone influence on the community structure of deep-sea benthos. In Proceedings of the sixth international symposium on fish physiology, toxicology and water quality. La Paz. Mexico. US Environmental Protection Agency. Ecosystems Research Division, Athens,121-133.

Li, J., Zhang, Y., Zhang, Y., Xiang, Z., Tong, Y., Qu, F. \& Yu, Z. (2014). Genomic characterization and expression analysis of five novel IL-17 genes in the Pacific oyster. Crassostrea gigas. Fish \& shellfish immunology, 40(2), 455-465. https://doi.org/10.1016/j.fsi.2014.07.026

López, C., Carballal, M.J., Azevedo, C. \& Villalba, A. (1997). Morphological characterization of the hemocytes of the clam. Ruditapes decussatus (Mollusca: Bivalvia). Journal of Invertebrate Pathology, 69(1), 51-57. http://doi.org/10.1006/jipa.1996.4639

Melzner, F., Thomsen, J., Koeve, W., Oschlies, A., Gutowska, M.A., Bange, H.W., ... \& Körtzinger, A. (2013). Future ocean acidification will be amplified by hypoxia in coastal habitats. Marine Biology, 160(8), 1875-1888. http://doi.org/ 10.1007/s00227-012-1954-1

Middelburg, J.J. \& Levin, L.A. (2009). Coastal hypoxia and sediment biogeochemistry. Biogeosciences Discussions, 6(2). https://doi.org/10.5194/bg-6-1273-2009

Moritz, K.M., Lim, G.B. \& Wintour, E.M. (1997). Developmental regulation of erythropoietin and erythropoiesis. American Journal of Physiology-Regulatory. Integrative and Comparative Physiology, 273(6), 1829-1844. http://doi.org/10.1152/ajpregu.1997.273.6.R1829

Nunez, R. (2001). DNA measurement and cell cycle analysis by flow cytometry. Current issues in molecular biology, 3 , 67-70. https://doi.org/10.21775/cimb.003.067

Ottaviani, E., Franchini, A., Barbieri, D. \& Kletsas, D. (1998). Comparative and morphofunctional studies on Mytilus 
galloprovincialis hemocytes: Presence of two agingrelated hemocyte stages. Italian Journal of Zoology, 65(4), 349-354.

Picot, S., Morga, B., Faury, N., Chollet, B., Dégremont, L., Travers, M.A., ... \& Arzul, I. (2019). A study of autophagy in hemocytes of the Pacific oyster, Crassostrea gigas. Autophagy, 15(10), 1801-1809. https://doi.org/10.1080/15548627.2019.1596490

Rabalais, N.N. \& Turner, R.E. (2001). Coastal hypoxia: consequences for living resources and ecosystems. American Geophyical Union. http://doi.org/10.2307/3069050

Soldatov, A.A. (2005). Peculiarities of organization and functioning of the fish red blood system. Journal of Evolutionary Biochemistry and Physiology, 41(3), 272281. http://doi.org/10.1007/s10893-005-0060-0

Soldatov, A.A., Kukhareva, T.A., Andreeva, A.Y., Parfenova, I.A., Rychkova, V.N., \& Zin'kova, D.S. (2017). The functional morphology of erythrocytes of the black scorpion fish Scorpaena porcus (Linnaeus, 1758) (Scorpaeniformes: Scorpaenidae) during hypoxia. Russian Journal of Marine Biology, 43(5), 368-373. http://doi.org/10.1134/S1063074017050091

Song, L., Wang, L., Qiu, L. \& Zhang, H. (2010). Bivalve immunity. In Invertebrate immunity. Springer. Boston. MA, 44-65. http://doi.org/10.1007/978-1-4419-8059-5_3

Strunjak-Perovic, I., Coz-Rakovac, R. \& Jadan, M. (2009). Seasonality of nuclear abnormalities in gilthead sea bream Sparus aurata (L.) erythrocytes. Fish physiology and biochemistry, 35(2), 287-291. http://doi.org/10.1007/s10695-008-9208-3

Sui, Y., Kong, H., Shang, Y., Huang, X., Wu, F., Hu, M. \& Wang, $Y$. (2016). Effects of short-term hypoxia and seawater acidification on hemocyte responses of the mussel Mytilus coruscus. Marine pollution bulletin, 108(1-2), 4652. http://doi.org/10.1016/j.marpolbul.2016.05.001.

Sun, J., Wu, X. \& Zhang, W. (2006). Morphological. structural and functional characteristics of the hemocytes of the oyster Crassostrea ariakensis. Journal of Shellfish Research, 25(1), 55-64. https://doi.org/10.2983/07308000(2006)25[55:MSAFCO]2.0.CO;2

Sussarellu, R., Dudognon, T., Fabioux, C., Soudant, P., Moraga, D. \& Kraffe, E. (2013). Rapid mitochondrial adjustments in response to short-term hypoxia and re-oxygenation in the Pacific oyster. Crassostrea gigas. Journal of Experimental Biology, 216(9), 1561-1569. http://doi.org/10.1242/jeb.075879

Sussarellu, R., Fabioux, C., Le Moullac, G., Fleury, E., \& Moraga, D. (2010). Transcriptomic response of the Pacific oyster Crassostrea gigas to hypoxia. Marine genomics, 3(3-4), 133-143 http://doi.org/10.1016/j.margen.2010.08.005.

Sussarellu, R., Fabioux, C., Sanchez, M.C., Le Goïc, N., Lambert, C., Soudant, P. \& Moraga, D. (2012). Molecular and cellular response to short-term oxygen variations in the Pacific oyster Crassostrea gigas. Journal of Experimental Marine Biology and Ecology, 412, 87-95. https://doi.org/10.1016/j.jembe.2011.11.007

Suzuki, T., \& Funakoshi, S. (1992). Isolation of a fibronectin-like molecule from a marine bivalve, Pinctada fucata, and its secretion by amebocytes. Zoological science, 9(3), 541550.

Takahashi, K.G., Izumi-Nakajima, N., \& Mori, K. (2017). Unique phagocytic properties of hemocytes of Pacific oyster crassostrea gigas against yeast and yeast cell-wall derivatives. Fish \& Shellfish Immunology, 70, 575-582. http://doi.org/10.1016/j.fsi.2017.09.027

Terahara, K., Takahashi, K.G., Nakamura, A., Osada, M., Yoda, M., Hiroi, T., ... \& Mori, K. (2006). Differences in integrindependent phagocytosis among three hemocyte subpopulations of the Pacific oyster "Crassostrea gigas". Developmental \& Comparative Immunology, 30(8), $667-$ 683. http://dx.doi.org/10.1016/j.dci.2005.09.009

Van der Knaap, W.P.W., Adema, C.M. \& Sminia, T. (1993). Invertebrate blood cells: morphological and functional aspects of the haemocytes in the pond snail Lymnaea stagnalis. Comparative Haematology International, 3(1), 20-26.

Van der Schatte Olivier, A., Jones, L., Vay, L.L., Christie, M., Wilson, J., \& Malham, S.K. (2020). A global review of the ecosystem services provided by bivalve aquaculture. Reviews in Aquaculture, 12(1), 3-25. https://doi.org/10.1111/raq.12301

Van der Weele, C.M., \& Jeffery, W. (2019). Cavefish Increase Red Blood Cell Development and Reprogram Metabolism as Adaptations to Environmental Hypoxia. bioRxiv. https://doi.org/10.1101/2019.12.12.874230

Vaquer-Sunyer, R. \& Duarte, C.M. (2008). Thresholds of hypoxia for marine biodiversity. Proceedings of the National Academy of Sciences, 105(40), 15452-15457 https://doi.org/10.1073/pnas.0803833105

Wang, L., Song, X. \& Song, L. (2018). The oyster immunity. Developmental \& Comparative Immunology, 80, 99-118. http://dx.doi.org/10.1016/j.dci.2017.05.025

Wang, W., Li, M., Wang, L., Chen, H., Liu, Z., Jia, Z., ... \& Song, L. (2017). The granulocytes are the main immunocompetent hemocytes in Crassostrea gigas. Developmental \& Comparative Immunology, 67, 221228. https://doi.org/10.1016/j.dci.2016.09.017

Wang, Y., Hu, M., Cheung, S.G., Shin, P.K.S., Lu, W. \& Li, J. (2012). Immune parameter changes of hemocytes in green-lipped mussel Perna viridis exposure to hypoxia and hyposalinity. Aquaculture, 356, 22-29. https://doi.org/10.1016/j.aquaculture.2012.06.001

Wang, Y., Hu, M., Li, Q., Li, J., Lin, D. \& Lu, W. (2014). Immune toxicity of $\mathrm{TiO}_{2}$ under hypoxia in the green-lipped mussel Perna viridis based on flow cytometric analysis of hemocyte parameters. Science of the total environment, 470, 791-799. http://doi.org/10.1016/j.scitotenv.2013.09.060.

Wu, F., Xie, Z., Lan, Y., Dupont, S., Sun, M., Cui, S., ... \& Lu, W. (2018). Short-term exposure of Mytilus coruscus to decreased $\mathrm{pH}$ and salinity change impacts immune parameters of their haemocytes. Frontiers in physiology, 9, 166. http://dx.doi.org/10.3389/fphys.2018.00166

Wu, R.S. (2002). Hypoxia: from molecular responses to ecosystem responses. Marine pollution bulletin, 45(112), 35-45. http://doi.org/10.1016/s0025-326x(02)00061-9.

Young, C.S., \& Gobler, C.J. (2020). Hypoxia and Acidification, Individually and in Combination, Disrupt Herbivory and Reduce Survivorship of the Gastropod, Lacuna vincta. Frontiers in Marine Science, 7, 785. https://doi.org/10.3389/fmars.2020.547276

Zhao, Y., Liu, J., Uthaipan, K., Song, X., Xu, Y., He, B., ... \& Dai, $M$. (2020). Dynamics of inorganic carbon and $\mathrm{pH}$ in a large subtropical continental shelf system: Interaction between eutrophication, hypoxia, and ocean acidification. Limnology and Oceanography, 65, 13591379. https://doi.org/10.1002/Ino.11393 